\section{A Fluorescent hPept1 Transporter Substrate for Uptake Screening}

\author{
Christopher P. Landowski, ${ }^{1}$ Hyo-kyung Han, ${ }^{1,2}$ \\ Kyung-Dall Lee, ${ }^{1}$ and Gordon L. Amidon ${ }^{1,3}$
}

Received July 21, 2003; accepted August 1, 2003

Purpose. To synthesize fluorescent analogues of hPept1 substrates, FITC-Val-OCH ${ }_{3}$, Lys-FITC-OH, and Lys-FITC-OCH $\mathrm{OH}_{3}$, and to characterize their hPept1 transporter-mediated uptake.

Methods. FITC analogues of amino acids were synthesized using established synthetic procedures, and the extent of their $\left[{ }^{3} \mathrm{H}\right] \mathrm{Gly}-\mathrm{Sar}$ uptake inhibition in HeLa/hPept1 cells was determined. The uptake of Lys-FITC-OCH ${ }_{3}$ was evaluated in $\mathrm{HeLa}, \mathrm{HeLa} / \mathrm{hPept} 1$, and Caco- 2 cells in the presence and absence of Gly-Sar using a fluorescence microscopy-based assay. The uptake and transport of the LysFITC analogues were also determined in Caco-2 cells using HPLC assays.

Results. In HeLa/hPept 1 cells, $\left[{ }^{3} \mathrm{H}\right] \mathrm{Gly}$-Sar uptake was significantly inhibited by Lys-FITC-OCH $3(74 \%)$ but not by FITC-Val-OCH $(22 \%)$. The uptake of Lys-FITC-OCH ${ }_{3}(100 \mu \mathrm{M})$ was approximately 10 -fold higher in $\mathrm{HeLa}$ /hPept1 cells. Also, Lys-FITC-OCH $(100 \mu \mathrm{M})$ uptake in HeLa/hPept1 and Caco- 2 cells was reduced by $77 \%$ and $80 \%$, respectively, in the presence of $1 \mathrm{mM}$ Gly-Sar. Dipeptides and cephalexin significantly reduced Lys-FITC-OCH${ }_{3}$ uptake in Caco-2 cells. The apical permeability of Lys-FITC-OCH $\left(1.5 \times 10^{6} \mathrm{~cm} / \mathrm{s}\right)$ in Caco-2 cells was significantly lowered in the presence of Gly-Sar. Fluorescence micrographs revealed that this analogue was localized in the cytoplasm and in the nucleus.

Conclusions. The combined results indicate that Lys-FITC-OCH $\mathrm{H}_{3}$ is recognized and transported by hPept 1 in HeLa/hPept 1 and by peptide transporters in Caco- 2 cells. The results also suggest that LysFITC-OCH $\mathrm{O}_{3}$ might be a useful fluorescent substrate for rapid assessment of peptide transporter activity in cells of interest.

KEY WORDS: fluorescent substrate; oligopeptide transporter; hPept1; HeLa; Caco-2; permeability.

\section{INTRODUCTION}

The human intestinal di/tripeptide transporter, hPept1, plays a nutritional role in transporting dietary peptides; however, in some cases it serves as a carrier for pharmacologically active peptide-like compounds. Because of its broad substrate specificity, the transporter is also known to contribute to the intestinal absorption of several nonpeptide drug compounds including oral $\beta$-lactam antibiotics (1), the antineoplastic agent bestatin (2), and an angiotensin-converting enzyme inhibitor (3). This wide substrate specificity allows the design of peptidomimetic prodrugs to increase the intestinal transport of low-permeability drug compounds or to potentially target tumor cells with anticancer drugs. This approach has been

\footnotetext{
${ }^{1}$ Department of Pharmaceutical Sciences, College of Pharmacy, University of Michigan, Ann Arbor, MI 48109.

${ }^{2}$ Current address: Department of Pharmacokinetics, Dynamics and Metabolism, Pfizer Global Research and Development, Ann Arbor, MI 48105.

${ }^{3}$ To whom correspondence should be addressed. (email: glamidon@ umich.edu)
}

successful in increasing the bioavailability of the antiviral drugs acyclovir and ganciclovir. Nucleoside antivirals such as acyclovir and ganciclovir are polar drugs with low membrane permeability and poor oral absorption $(4,5)$. The L-valyl ester prodrugs valacyclovir and valganciclovir increase their parent drug bioavailability three- to fivefold (6) and 10-fold (7), respectively, in humans because of their affinity for hPept1 $(8,9)$. Targeted delivery of drugs to cancer cells would be possible if the peptide transporter exhibits differential expression in cancer cells compared to normal healthy cells. Pancreatic tumors have been shown to express higher levels of Pept1 than normal pancreatic cells (10), thereby providing a potential target for delivery of anticancer drugs. Based on this rationale, the in vitro delivery of $\delta$-aminolevulinic acid to rat pancreatic tumor cells via the Pept1 transporter has been reported (11).

The peptide transporters are capable of carrying natural substrates up to at least 522 Daltons (tritryptophan) (12). The promiscuous nature of the hPept1 transporter, together with its ability to carry "large" substrates, makes it an attractive carrier for anticancer compounds. The characterization of the peptide transporter uptake activity in different cell types in vitro or different tissues in vivo could require the screening of many samples. In particular, if cancer cell libraries need to be screened rapidly, suitable alternatives to tedious HPLC or hazardous radioactive assays would be highly beneficial. Fluorescence-based assays offer high sensitivity and are amenable to rapid assessment with multiwell plate readers. Several studies with fluorescent peptide transporter substrates have been reported. In one such study, fluorescent peptide analogues of Val-Lys and Lys-Sar were synthesized by Abe et al. and examined for their transport in Caco-2 cells (13). The authors found that although the fluorescent analogues do not appear to be transported in Caco- 2 cells, they did exhibit high affinity for the transporter (13). Groneberg et al. reported the synthesis and ex vivo uptake studies of D-Ala-Lys-AMCA (7-amino-4-methylcoumarin-3-acetic acid) in murine small intestine (12). The authors demonstrated and visualized mammalian intestinal peptide transport ex vivo and identified the cellular sites of Pept1 expression in the intestinal tract and suggest that such visualization assays might be a useful tool to characterize compounds that use Pept1 for uptake into epithelial cells or that inhibit transport activity specifically.

In this study we report the synthesis of fluorescent analogues of the amino acids valine and lysine, FITC-Val- $\mathrm{OCH}_{3}$, Lys-( ${ }^{\varepsilon}-$ FITC)-OH (Lys-FITC-OH), and Lys-( ${ }^{\varepsilon}-$ FITC)$\mathrm{OCH}_{3}\left(\mathrm{Lys}-\mathrm{FITC}-\mathrm{OCH}_{3}\right)$, by conjugation of the $\alpha$-amino group of Val or the $\varepsilon$-amino group of Lys or its methyl ester to the fluorescent molecule fluorescein isothiocyanate (FITC). The fluorescent analogues were then tested for their ability to inhibit the uptake of $\left[{ }^{3} \mathrm{H}\right] \mathrm{Gly}-\mathrm{Sar}$, a Pept1 substrate, in HeLa cells overexpressing hPept1. We further describe the cellular uptake of Lys-FITC-OCH $\mathrm{OH}_{3}$ in normal HeLa cells, in HeLa cells overexpressing hPept1, and in Caco- 2 cells in the presence and absence of Gly-Sar using a simplified fluorescence assay. The uptake profiles obtained using fluorescencebased assays were corroborated using conventional HPLC and radioactivity methods. The involvement of hPept 1 in mediating active transport of Lys-FITC- $\mathrm{OCH}_{3}$ and its free acid form was also examined with transport studies in Caco-2 
monolayers and with conventional fluoroscopic images of Lys-FITC-OCH $\mathrm{O}_{3}$ uptake in HeLa/hPept1 cells.

\section{MATERIALS AND METHODS}

\section{Materials}

$\left[{ }^{3} \mathrm{H}\right]$-Glycyl-sarcosine (sp. act., $400 \mathrm{mCi} / \mathrm{mmol}$ ) was purchased from Moravek Biochemicals (Brea, CA). All other chemicals were purchased from Sigma (St. Louis, MO) unless otherwise specified. Cell culture reagents were obtained from Gibco (Grand Island, NY), and cell culture supplies were from Corning (Corning, NY) and Falcon (Lincoln Park, NJ).

\section{Cell Culture}

Caco- 2 cells were obtained from American Type Culture Collection (ATCC HTB37, Passage number 30-35) and were maintained in Dulbecco's modified Eagle's medium (DMEM) supplemented with 10\% fetal bovine serum (FBS), $1 \%$ MEM nonessential amino acids, $1 \mathrm{mM}$ sodium pyruvate, and $1 \%$ L-glutamine. HeLa cells were obtained from ATCC and grown in similar conditions. All cells were grown in an atmosphere of $5 \% \mathrm{CO}_{2}$ and $90 \%$ relative humidity at $37^{\circ} \mathrm{C}$.

\section{RT-PCR Assay for hPept1 mRNA Expression}

For RT-PCR, total RNA from the tissue and cell samples was purified using Trizol reagent (Gibco, Grand Island, NY). One microgram of total RNA from each sample was subjected to RT-PCR (PCR Access system, Promega, Madison, WI) using hPept1 specific primers. The primers corresponded to nucleotide positions 342-360 (forward primer) and 15751592 (reverse primer) of the cDNA. The first strand cDNA was synthesized using AMV reverse transcriptase (AMV RT) at $48^{\circ} \mathrm{C}$ for $45 \mathrm{~min}$. This was followed by a 2 -min cycle at $94^{\circ} \mathrm{C}$ to inactivate AMV RT and to denature the primers and cDNA. The PCR was performed for 25 cycles of $94^{\circ} \mathrm{C}$ for $30 \mathrm{~s}$, primer annealing for $1 \mathrm{~min}$ at $54^{\circ} \mathrm{C}$, extension at $68^{\circ} \mathrm{C}$ for $2 \mathrm{~min}$, and a final extension at $68^{\circ} \mathrm{C}$ for $7 \mathrm{~min}$. The experimental conditions were optimized to ensure linear amplification of the PCR product. The expected hPept1 PCR fragment was $1.2 \mathrm{~kb}$. The reaction mixture was separated on a $4-20 \%$ TBE -polyacrylamide gel (Invitrogen, Carlsbad, CA) and visualized with SYBR Green nucleic acid gel stain (Molecular Probes, Eugene, OR).

\section{Adenoviral Infection of HeLa Cells}

Ad.RSVhPept1 was prepared and was used to infect HeLa cell cultures as described by Hsu et al. (14). The HeLa cells were seeded onto six-well plates at a density of $1 \times 10^{5}$ cells $/ \mathrm{cm}^{2}$ and grown for $24 \mathrm{~h}$. The cells were infected with 5000 viral particles per cell, and uptake experiments were conducted at $48 \mathrm{~h}$ postinfection.

\section{Lys-(N ${ }^{\varepsilon}$-FITC)-OH and Lys-( ${ }^{\varepsilon}$-FITC)-OCH 3 Synthesis}

Boc-Lys-OH or Boc-Lys- $\mathrm{OCH}_{3}(0.67 \mathrm{mmol})$ was dissolved in $20 \mathrm{ml}$ dimethylformamide (DMF) and cooled to $0^{\circ} \mathrm{C}$. To this $237 \mathrm{mg}(0.61 \mathrm{mmol})$ fluorescein-5-isothiocyanate (FITC) and $93 \mu \mathrm{l}(0.67 \mathrm{mmol})$ of triethylamine $\left(\mathrm{Et}_{3} \mathrm{~N}\right)$ were added. After stirring at $0^{\circ} \mathrm{C}$ for $15 \mathrm{~min}$ and then at room temperature for $2 \mathrm{~h}$, the reaction mixture was diluted with 50 ml ethyl acetate and washed successively with $0.6 \mathrm{M}$ citric acid $(40 \mathrm{~mL})$, water $(30 \mathrm{~mL})$, and brine $(20 \mathrm{~mL})$. The organic layer was dried over sodium sulfate and concentrated under vacuum. The resulting residue was purified by column chromatography using a mixture of chloroform:methanol:acetic acid (15:1:0.08, v/v) as solvent. After evaporation of the desired fractions, the obtained yellow intermediate was treated with $10 \mathrm{ml}$ of trifluoroacetic acid $/ \mathrm{CH}_{2} \mathrm{Cl}_{2}(1: 1, \mathrm{v} / \mathrm{v})$ and stirred at $0^{\circ} \mathrm{C}$ for $30 \mathrm{~min}$. The excess acid was removed in vacuo. The resulting residue was triturated with diethylether $\left(\mathrm{Et}_{2} \mathrm{O}\right)$ and dried in vacuo to obtain the desired product as an orange powder. The overall yield for the two lysine-FITC analogues was $\sim 91 \%$. Electrospray ionization mass spectra (ESI-MS) were obtained on a Thermoquest LCQ electrospray ionization mass spectrometer. The observed molecular weights of the FITC analogues were found to be similar to those predicted from their expected structures. Lys-FITC-OH, ESI-MS $\mathrm{m} / \mathrm{z}=536.0(\mathrm{M}+\mathrm{H})^{+} ;$Lys-FITC-OCH 3, ESI-MS m/z $=549.9$ $(\mathrm{M}+\mathrm{H})^{+}$. The FITC analogue structures are shown in Fig. 1.

\section{Val-FITC-OCH ${ }_{3}$ Synthesis}

Val- $\mathrm{OCH}_{3}(0.67 \mathrm{mmol})$ was dissolved in $20 \mathrm{ml} \mathrm{DMF}$ and cooled to $0^{\circ} \mathrm{C}$. To this $237 \mathrm{mg}(0.61 \mathrm{mmol})$ of FITC and $93 \mu \mathrm{l}$ $(0.67 \mathrm{mmol})$ of $\mathrm{Et}_{3} \mathrm{~N}$ were added. After stirring at $0^{\circ} \mathrm{C}$ for 15 min and then at room temperature for $2 \mathrm{~h}$, the reaction mix-<smiles>N[C@@H](CCCNC(=S)Nc1ccc2c(c1)C(=O)OC21c2ccc(O)cc2Oc2cc(O)ccc21)C(=O)O</smiles>

$$
\begin{array}{lll}
\mathrm{R}=\mathrm{H} ; & \text { Lys-(N } \left.{ }^{\varepsilon}-\mathrm{FITC}\right)-\mathrm{OH} & \text { (M.W.: 535) } \\
\mathrm{R}=\mathrm{CH}_{3} ; \text { Lys-(N } \mathrm{N}^{\varepsilon}-\text { FITC) }-\mathrm{OCH}_{3} & \text { (M.W.: 549) }
\end{array}
$$<smiles>COC(=O)[C@H](NC(=S)Nc1ccc2c(c1)C(=O)OC21c2ccc(O)cc2Oc2cc(O)ccc21)C(C)C</smiles>

FITC-Val-OCH $\mathrm{H}_{3}$ (M.W.: 520)

Fig. 1. Structures of Lys-( $\mathrm{N}^{\varepsilon}$-FITC)-OH, Lys-( $\left.\mathrm{N}^{\varepsilon}-\mathrm{FITC}\right)-\mathrm{OCH}_{3}$, and FITC-Val- $\mathrm{OCH}_{3}$. 
ture was diluted with $50 \mathrm{ml}$ ethyl acetate and washed successively with $0.6 \mathrm{M}$ citric acid $(40 \mathrm{ml})$, water $(30 \mathrm{ml})$, and brine $(20 \mathrm{ml})$. The organic layer was dried over sodium sulfate and concentrated under vacuum. The resulting residue was purified by column chromatography using a mixture of chloroform:methanol:acetic acid (15:1:0.08, v/v) as solvent. After evaporation of the desired fractions, the residue was triturated with $\mathrm{Et}_{2} \mathrm{O}$ and dried in vacuo to obtain the desired product as an orange powder. The overall yield was $90 \%$. Electrospray ionization mass spectra (ESI-MS) were obtained on a Thermoquest LCQ electrospray ionization mass spectrometer. The observed molecular weight of the FITC analogue was found to be similar to those predicted from its expected structure. Val-FITC-OCH ${ }_{3}$, ESI-MS m/z $=521.1$ $(\mathrm{M}+\mathrm{H})^{+}$. The Val-FITC-OCH${ }_{3}$ structure is shown in Fig. 1.

\section{HPLC Assay of FITC Analogues}

Samples containing the Lys-FITC analogues were analyzed using a high-performance liquid chromatography (HPLC) system consisting of a pump (Waters, Model 510, Milford, MA), an automatic injector (Waters, WISP model 712), a reversed-phase column (Ultrasphere, 5- $\mu \mathrm{m}, \mathrm{C}-18$, $4.6 \times 250 \mathrm{~mm}$, Beckman), and a fluorescent detector (Waters, Model 470) set at an excitation wavelength of $490 \mathrm{~nm}$ and an emission wavelength of $525 \mathrm{~nm}$. The mobile phase was a (82/ $18, \mathrm{v} / \mathrm{v})$ mixture of phosphate-buffered saline $(\mathrm{pH} 7.0)$ and acetonitrile. The compounds were analyzed over $23 \mathrm{~min}$ at a flow rate of $1 \mathrm{ml} / \mathrm{min}$. The pump, data acquisition, and integration were controlled with Millennium ${ }^{\circledR}$ software (Waters).

\section{Fluorescent Uptake Assays}

The culture medium in the six-well culture plate was removed, the cells were washed with PBS pH 7.4, and $2 \mathrm{ml}$ of uptake medium containing $(25-100 \mu \mathrm{M})$ Lys-FITC-OCH was added to the wells. The uptake medium contained 145 $\mathrm{mM} \mathrm{NaCl}, 3 \mathrm{mM} \mathrm{KCl}, 1 \mathrm{mM} \mathrm{NaH} \mathrm{PO}_{4}, 1 \mathrm{mM} \mathrm{CaCl}, 0.5 \mathrm{mM}$ $\mathrm{MgCl}_{2}, 5 \mathrm{mM}$ D-glucose, and $5 \mathrm{mM}$ MES (pH 6.0). The fluorescent analogue was incubated with the cells for $45 \mathrm{~min}$ at $37^{\circ} \mathrm{C}$, after which the buffer was removed, and the cells were washed three times with room-temperature PBS. Lys-FITC$\mathrm{OCH}_{3}$ uptake was determined by fluorescence measurements using an inverted fluorescence microscope (Zeiss Axiovert 135 TV). For each treatment, multiple images were randomly taken using the $10 \times$ objective from independent wells and then quantified using image analysis (Metamorph, Universal Imaging Corp., Downingtown, PA). The cells were then scraped off in water, lysed by probe-sonication for $15 \mathrm{~s}$ three times, and protein concentration was determined with a Protein Assay DC kit (BioRad, Hercules, CA). After subtraction of background fluorescence, the fluorescent intensity of each image was integrated and reported as an integrated fluorescence value per milligram of protein (integrated value/mg protein).

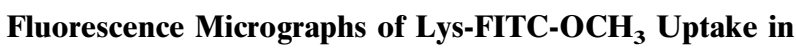 HeLa/hPept1 Cells}

HeLa cells were grown on chamber slides (Nalge Nunc International, Rochester, NY) and infected with Ad.RSVhPept1 as previously described (14). Lys-FITC$\mathrm{OCH}_{3}(50 \mu \mathrm{M})$ was incubated with the cells for $45 \mathrm{~min}$ at $37^{\circ} \mathrm{C}$ in uptake buffer, after which the buffer was removed, and the cells were washed three times with cold uptake buffer. The HeLa/hPept 1 cells were fixed with $4 \%$ paraformaldehyde for $15 \mathrm{~min}$ at $4^{\circ} \mathrm{C}$ and washed 4 times with PBS at room temperature. The slides were mounted in Fluoromount-G medium (Electron Microscopy Sciences, Fort Washington, PA), and micrographs of cell images were obtained using an inverted fluorescence microscope (Zeiss Axiovert 135 TV) with $50 \times$ and $100 \times$ objectives.

\section{Caco-2 Monolayer Transport and Stability Studies}

The Caco-2 permeability of Lys-FITC-OH, Lys-FITC$\mathrm{OCH}_{3}$, and FITC-Val-OCH $(50 \mu \mathrm{M})$ were evaluated as previously described (15). The transport of the FITC analogues in the apical-to-basolateral (AP-to-BL) and in the basolateral-to-apical (BL-to-AP) directions was determined with and without Gly-Sar $(10 \mathrm{mM})$ in collagen-coated transwell pates ( $0.4 \mu \mathrm{m}$ pore size, $12 \mathrm{~mm}$ diameter, Costar, Cambridge, MA). The concentration of the FITC analogue in the receiver and donor compartments were analyzed using HPLC. The apparent permeability $\left(\mathrm{P}_{\mathrm{app}}\right)$ in either direction was calculated using the following equation:

$$
P_{a p p}=\frac{V_{r}}{A \times C_{0}} \times \frac{d C_{r}}{d_{t}}
$$

where $\mathrm{V}_{\mathrm{r}}$ is the receiver volume, $\mathrm{A}$ is the surface area of the exposed monolayer, $\mathrm{C}_{0}$ is the concentration of the FITC analogue in the donor solution, and $\mathrm{dC}_{\mathrm{r}} / \mathrm{d}_{\mathrm{t}}$ is the rate of change of concentration in the receiver solution.

The stability of donor solutions of Lys-FITC-OCH${ }_{3}$ and Lys-FITC-OH bathing either the apical side or the basolateral side was examined at $90 \mathrm{~min}$ of the transport experiments. The samples were assayed with HPLC to determine the mode and extent of degradation of the analogues when in contact with Caco-2 monolayers. The receiver solution in AP-to-BL transport experiments was also assayed with HPLC to determine metabolism of the analogues following passage across Caco-2 cells.

\section{Inhibition Studies}

For $\left[{ }^{3} \mathrm{H}\right] \mathrm{Gly}-\mathrm{Sar}$ uptake inhibition assays, cells were seeded in 12 -well culture plates $\left(3.8 \mathrm{~cm}^{2}\right.$ growth area) at a density of $10^{5}$ cells $/ \mathrm{cm}^{2}$. Two days postinfection, HeLa/hPept1 cells were washed with $\mathrm{pH} 6.0$ uptake buffer before addition of substrates and inhibitors. Solutions containing $1 \mathrm{mM}$ of the test FITC analogue and $20 \mu \mathrm{M}\left[{ }^{3} \mathrm{H}\right] \mathrm{Gly}-\mathrm{Sar}(0.4 \mu \mathrm{Ci} / \mathrm{ml})$ was added to each well and incubated for $30 \mathrm{~min}$ at $25^{\circ} \mathrm{C}$. The cells were then washed with ice-cold $\mathrm{pH} 6.0$ uptake buffer three times to stop cellular uptake. One milliliter of $1 \mathrm{M} \mathrm{NaOH} /$ $1.5 \%$ Triton $\mathrm{X}-100$ was then added to each well and incubated for $30 \mathrm{~min}$ at $25^{\circ} \mathrm{C}$. The cells were scraped off and transferred into vials containing $4 \mathrm{ml}$ of scintillation cocktail. The samples were analyzed for $\left[{ }^{3} \mathrm{H}\right] \mathrm{Gly}-\mathrm{Sar}$ content by scintillation counting (Beckman LS-9000, Beckman Instruments, Fullerton, $\mathrm{CA})$, and the protein concentrations determined.

In a second inhibition assay, Lys-FITC-OCH $\mathrm{H}_{3}$ uptake into Caco- 2 cells was determined in the presence of the dipeptides Gly-Pro and Gly-Phe and in the presence of Lys or cephalexin. Thus, Lys-FITC- $\mathrm{OCH}_{3}$ uptake from solutions containing $50 \mu \mathrm{M}$ Lys-FITC- $\mathrm{OCH}_{3}$, and known concentra- 
tions of the inhibitors were determined and compared to that from a control solution. The inhibitor concentrations used were as follows: $30 \mathrm{mM}$ lysine, $10 \mathrm{mM}$ Gly-Pro, $10 \mathrm{mM}$ GlyPhe, and $10 \mathrm{mM}$ cephalexin. One milliliter of the test solution was added to cells and agitated on a plate shaker at $25^{\circ} \mathrm{C}$. After $30 \mathrm{~min}$ incubation, the cells were washed with cold uptake buffer three times, water was added, and cells were scraped and probe-sonicated three times for $15 \mathrm{~s}$. The lysate was treated with TCA (3-5\%), vortexed, and centrifuged 5 min at $3000 \mathrm{rpm}$. The supernatant was filtered through a $0.45-$ $\mu \mathrm{m}$ membrane filter and analyzed by HPLC. The protein concentration was determined from the pre-TCA-treated sample using the Protein Assay DC kit (BioRad).

\section{RESULTS}

\section{RT-PCR Assay for hPept1 mRNA Expression}

The hPept 1 mRNA expression results from HeLa, HeLa/ hPept1, and Caco-2 cells are shown in Fig. 2. A 1.2-kb product was detected in all three samples, confirming the presence of hPept1 in all three cells. A semiquantitative estimate of mRNA expression using RT-PCR suggests that expression was in the order HeLa/hPept1 > Caco-2 cells > HeLa cells. The hPept1 mRNA expression was quite insignificant in normal HeLa cells, whereas its expression in HeLa/hPept1 cells was about 6-fold and 2-fold higher compared to normal HeLa cells and Caco- 2 cells, respectively.

\section{$\left[{ }^{3} \mathrm{H}\right]$ Gly-Sar Uptake Inhibition by FITC Analogues in HeLa/hPept1 Cells}

The $\left[{ }^{3} \mathrm{H}\right]$ Gly-Sar uptake results in the presence and absence of Lys-FITC-OCH $\mathrm{H}_{3}$ or FITC-Val-OCH $\mathrm{OCH}_{3}$ in HeLa/ hPept1 cells are shown in Fig. 3. It is evident that both the FITC analogues were capable of inhibiting Gly-Sar uptake, suggesting their affinity for the hPept1 transporter. However, Gly-Sar uptake inhibition was quite significant with LysFITC-OCH $3(74 \%, p<0.001)$, compared to only $22 \%$ with FITC-Val-OCH $\mathrm{O}_{3}$. Thus, Lys-FITC-OCH $\mathrm{H}_{3}$ appears to exhibit a much higher affinity for hPept1 than FITC-Val-OCH $\mathrm{CH}_{3}$ and was chosen for more detailed uptake and inhibition studies.

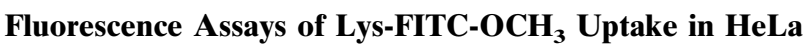 and HeLa/hPept1 Cells}

The uptake results of $100 \mu \mathrm{M}$ Lys-FITC-OCH${ }_{3}$ in normal HeLa and HeLa/hPept1 cells determined using a fluorescence

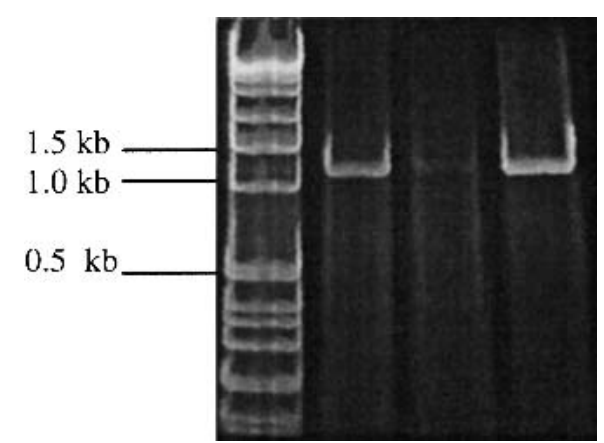

Fig. 2. RT-PCR quantification of hPept 1 mRNA in Caco-2 and HeLa cells. Lane 1, MW markers; lane 2, Caco-2 cell RNA; lane 3, HeLa cell RNA; lane 4, HeLa cell RNA from cells infected with adenovirus-containing hPept1.

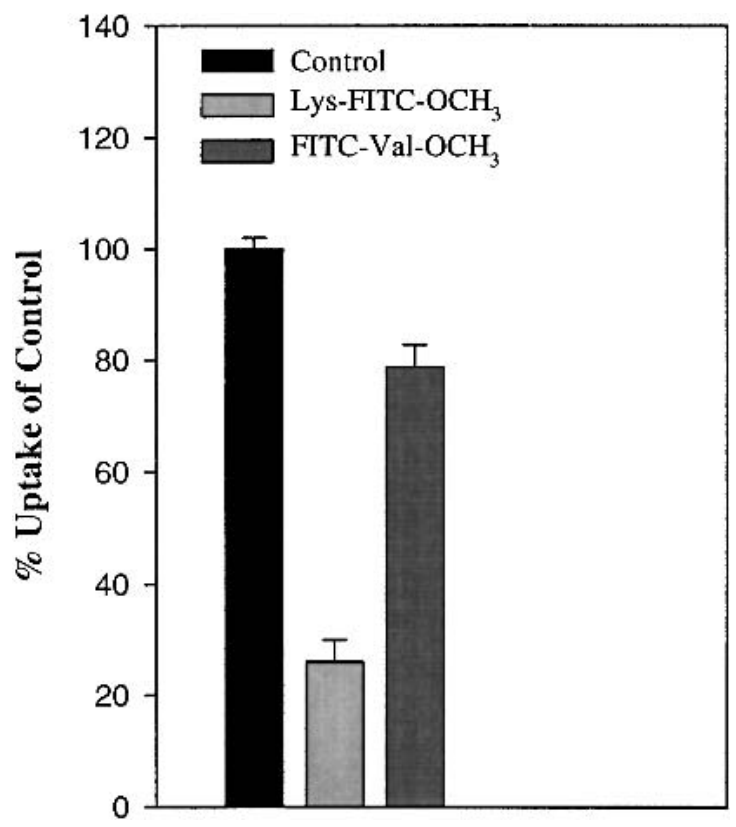

Fig. 3. Lys-FITC-OCH $3(1 \mathrm{mM})$ and FITC-Val-OCH $3(1 \mathrm{mM})$ inhibition of $\left[{ }^{3} \mathrm{H}\right] \mathrm{Gly}-\mathrm{Sar}$ uptake $(20 \mu \mathrm{M}, 0.5 \mu \mathrm{Ci} / \mathrm{ml})$ in $\mathrm{HeLa} / \mathrm{hPept} 1$ cells (mean $\pm \mathrm{SD}, \mathrm{n}=4$ ).

assay are shown in Fig. 4. The results in Fig. 4 clearly indicate that Lys-FITC-OCH $\mathrm{OCH}_{3}$ uptake is approximately 10-fold higher in HeLa cells overexpressing hPept1. The uptake of $100 \mu \mathrm{M}$ Lys-FITC-OCH $\mathrm{OCH}_{3}$ in HeLa/hPept1 cells was found to be sig-

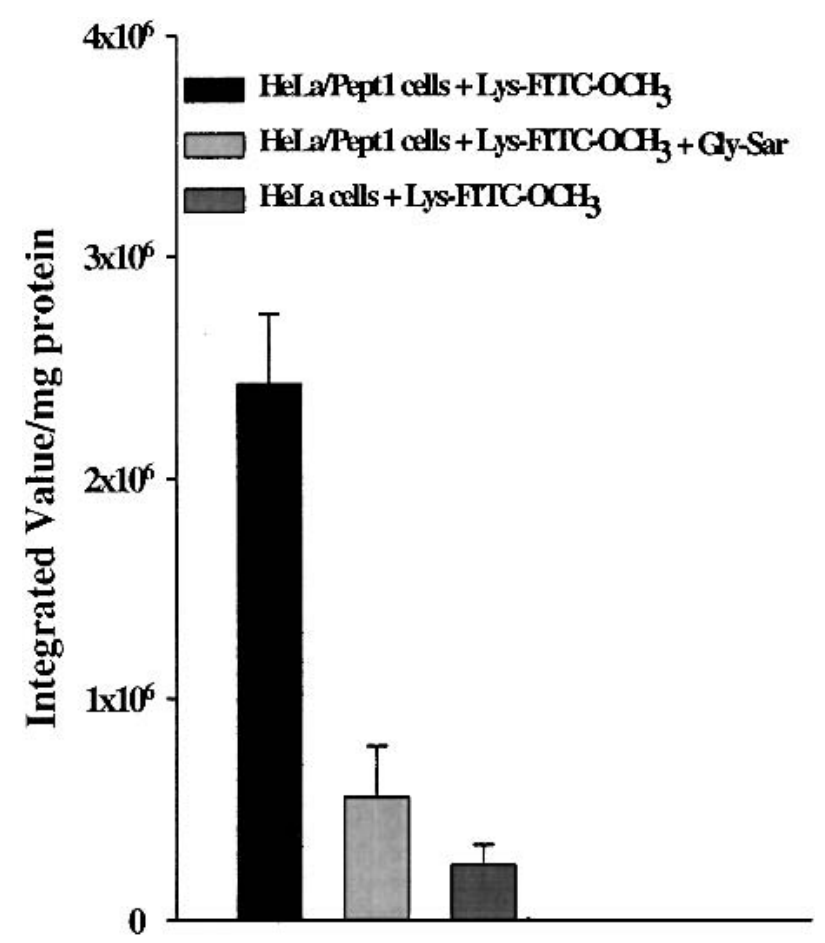

Fig. 4. The uptake of Lys-FITC-OCH $(100 \mu \mathrm{M})$ in HeLa/hPept1 and normal HeLa cells. Gly-Sar $(1 \mathrm{mM})$ was used as an inhibitor in the virus-infected $\mathrm{HeLa} / \mathrm{hPept} 1$ cells. HeLa/hPept 1 cells treated with $100 \mu \mathrm{M}$ Lys-FITC-OCH ${ }_{3}$ (mean \pm SEM, nine wells); HeLa/hPept1

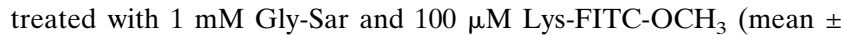
SEM, six wells); HeLa cells treated with $100 \mu \mathrm{M}$ Lys-FITC-OCH (mean \pm SEM, nine wells). 
nificantly inhibited $(77 \% ; \mathrm{p}<0.001)$ in the presence of $1 \mathrm{mM}$ Gly-Sar, indicating competitive hPept1 transport (Fig. 4).

The Lys-FITC-OCH $\mathrm{OH}_{3}$ uptake in HeLa and HeLa/hPept1 cells at three different concentrations $(25,50$, and $100 \mu \mathrm{M})$ determined with fluorescence assays is shown in Table I. The Lys-FITC-OCH $\mathrm{OH}_{3}$ uptake in $\mathrm{HeLa} / \mathrm{hPept} 1$ cells increased with Lys-FITC-OCH ${ }_{3}$ concentration and appears to show saturable behavior beyond $50 \mu \mathrm{M}$. Thus, the enhancement in uptake from $25 \mu \mathrm{M}$ to $50 \mu \mathrm{M}$ was about 5.5 -fold, whereas it increased only about 1.5 -fold with increasing concentration from $50 \mu \mathrm{M}$ to $100 \mu \mathrm{M}$. It was also found that Lys-FITC$\mathrm{OCH}_{3}$ uptake in HeLa/hPept1 cells was 10- to 100-fold higher than the uptake in normal HeLa cells at a given concentration. On the other hand, uptake of Lys-FITC-OCH 3 in normal HeLa cells exhibited a relatively large increase at the highest concentration of $100 \mu \mathrm{M}$ examined compared to that at $25 \mu \mathrm{M}$ and $50 \mu \mathrm{M}$.

\section{Fluorescence Assays of Lys-FITC-OCH $\mathrm{H}_{3}$ Uptake in Caco-2 Cells}

The uptake of $100 \mu \mathrm{M}$ Lys-FITC-OCH $\mathrm{H}_{3}$ in Caco- 2 cells determined with fluorescence assays in the presence and absence of $1 \mathrm{mM}$ Gly-Sar is shown in Fig. 5. The extent of Lys-FITC-OCH $\mathrm{OH}_{3}$ uptake inhibition by $1 \mathrm{mM}$ Gly-Sar $(80 \%)$, was similar to the Lys-FITC-OCH 3 uptake inhibition seen in HeLa/hPept1 cells (Fig. 4). More interestingly, the fluorescent uptake intensities of $100 \mu \mathrm{M}$ Lys-FITC-OCH $\mathrm{OCH}_{3}$ in HeLa, Caco-2, and HeLa/hPept1 cells determined under similar experimental conditions (integrated value/mg protein values of $250,000,500,000$ and $2,450,000)$ appear to be related to hPept1 mRNA expression levels (Fig. 2). Although the hPept1 mRNA expression levels are not quite quantitative, the enhanced fluorescent intensities with increased hPept1 expression in the three cells further supports cellular uptake of the FITC analogue via hPept1-mediated transport.

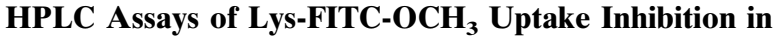 Caco-2 Cells}

The Caco-2 uptake results of $50 \mu \mathrm{M}$ Lys-FITC-OCH $\mathrm{OCH}_{3}$ in the presence of several inhibitors that were quantified using HPLC assays are shown in Fig. 6. Thus, the small dipeptides Gly-Pro and Gly-Phe, as well as cephalexin, known hPept1 substrates, significantly reduced Lys-FITC-OCH $\mathrm{H}_{3}$ uptake $(\mathrm{p}<$ 0.01 ). The extent of inhibition was $44 \%$ by Gly-Pro, $68 \%$ by Gly-Phe, and $67 \%$ by cephalexin. Uptake inhibition by lysine

Table I. Lys-FITC-OCH ${ }_{3}$ Uptake in Normal HeLa and HeLa/hPept1 Cells Determined Using Fluorescence Assays ${ }^{a}$

\begin{tabular}{ccr}
\hline & \multicolumn{2}{c}{$\begin{array}{c}\text { Integrated fluorescence } \\
\text { intensity/mg protein }\left(\times 10^{7}\right)\end{array}$} \\
\cline { 2 - 3 } $\begin{array}{c}\text { Lys-FITC-OCH} \\
\text { concentration }(\mu \mathrm{M})\end{array}$ & \multicolumn{1}{c}{ HeLa } & HeLa/hPept1 \\
\hline 25 & $0.03 \pm 0.01$ & $3.03 \pm 1.83^{b}$ \\
50 & $0.16 \pm 0.13$ & $16.58 \pm 3.43^{b}$ \\
100 & $2.51 \pm 0.88$ & $24.24 \pm 3.14^{b}$ \\
\hline
\end{tabular}

${ }^{a}$ All values expressed as mean \pm SEM of experiments from 9-10 wells.

${ }^{b}$ p-value $<0.001$ compared to corresponding uptake in normal HeLa cells.

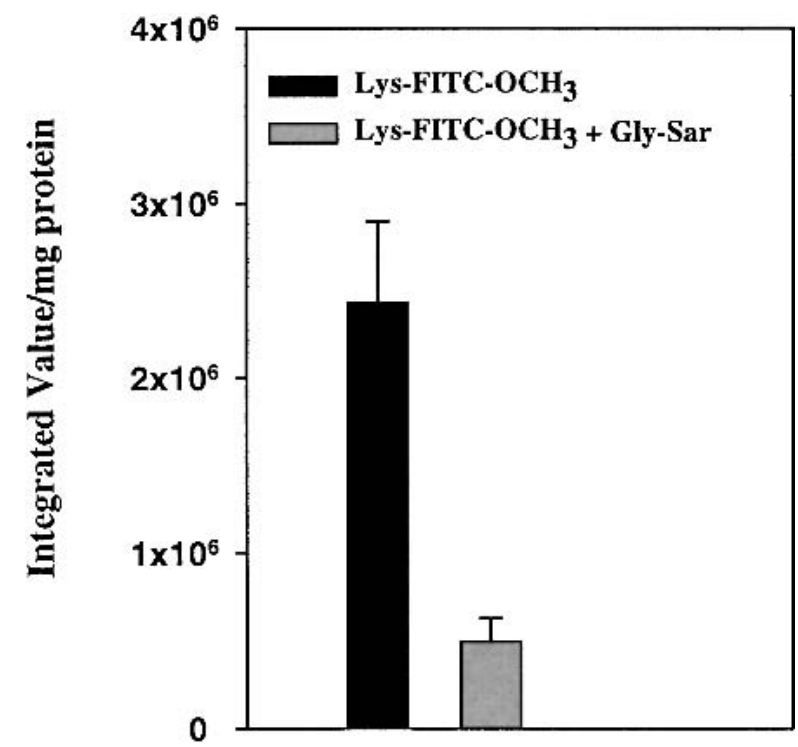

Fig. 5. Caco-2 cell uptake of $100 \mu \mathrm{M}$ Lys-FITC-OCH${ }_{3}$ with and without $1 \mathrm{mM}$ Gly-Sar inhibitor (mean \pm SEM, nine wells each); $\mathrm{p}<0.001$.

was found to be insignificant (5\%). These results obtained through assay of cellular Lys-FITC-OCH$H_{3}$ content using HPLC corroborate that cellular uptake of the FITC analogue occurs via a peptide transporter-mediated pathway.

\section{Fluorescence Micrographs of Lys-FITC-OCH $\mathrm{CH}_{3}$ Uptake in HeLa/hPept1 Cells}

Typical fluorescence micrographs of HeLa/hPept1 cells incubated with Lys-FITC-OCH $\mathrm{OH}_{3}$ using cell microscopy under high magnification $(50 \times)$ with an inverted fluorescence microscope are shown in Fig. 7. The micrographs indicate that the chromophore is localized in the cytoplasm as well as in the nucleus. In contrast, no fluorescence was evident with normal HeLa cells, indicating negligible uptake into cells or cell surface binding.

\section{Caco-2 Permeability and Lys-FITC Analogue Stability}

The apparent permeabilities of the three FITC analogues in the apical-to-basolateral (AP-to-BL) direction are shown in Table II. The AP-to-BL permeability of Lys-FITC- $\mathrm{OCH}_{3}$

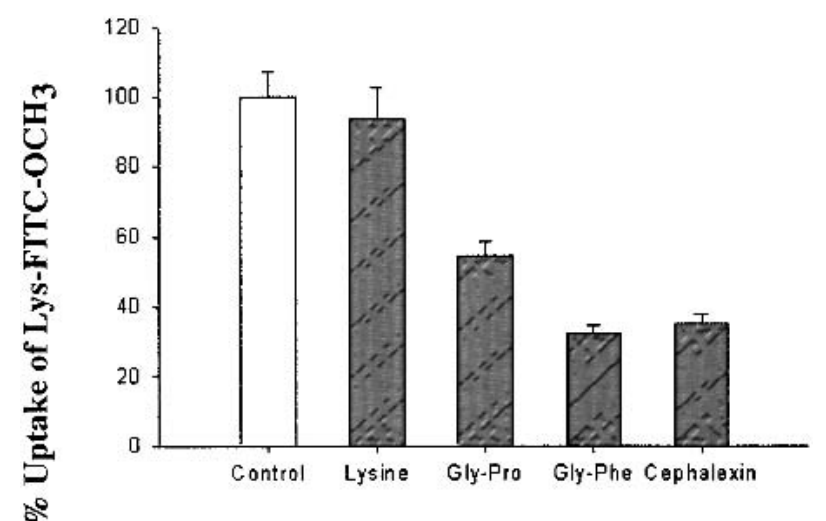

Fig. 6. Inhibition of Lys-FITC-OCH 3 uptake in Caco-2 cells. Control $0.05 \mathrm{mM}$, Lysine $30 \mathrm{mM}$, Gly-Pro $10 \mathrm{mM}$, Gly-Phe $10 \mathrm{mM}$, cephalexin $10 \mathrm{mM}$ (mean $\pm \mathrm{SEM}$, four wells). 


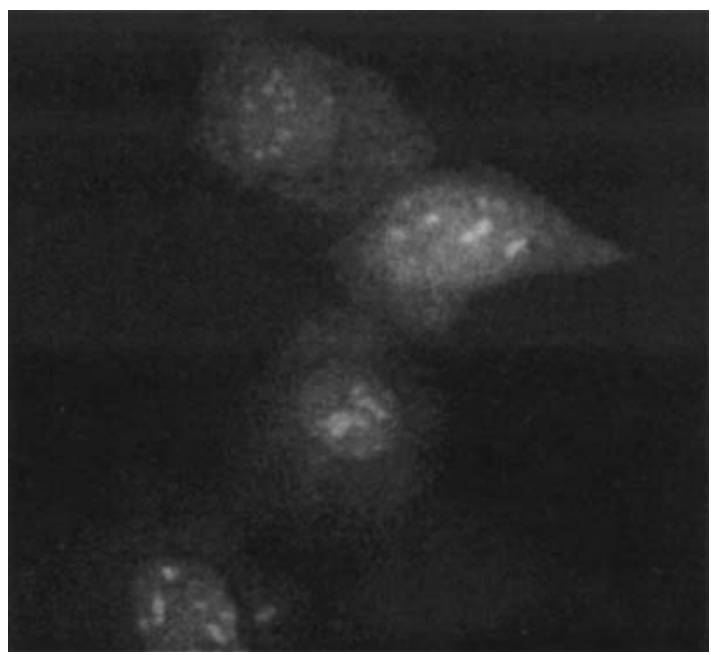

Fig. 7. Lys-FITC-OCH 3 uptake into $\mathrm{HeLa}$ /hPept1 cells.

was similar to that observed for Lys-FITC-OH, indicating that both analogues are equally permeable. In comparison, the AP-to-BL permeability of Val-FITC-OCH $\mathrm{H}_{3}$ was about 10 -fold lower than that of the Lys-FITC analogues. Further, the presence of $10 \mathrm{mM}$ Gly-Sar significantly inhibited the permeability of both Lys-FITC analogues $(\mathrm{p}<0.001)$. The basolateralto-apical (BL-to-AP) permeabilities of the two Lys-FITC analogues were similar to each other and roughly 7-fold lower than their AP-to-BL permeability (Table II). Interestingly, the AP-to-BL permeability of Lys-FITC-OCH $\mathrm{H}_{3}$ in the presence of $10-\mathrm{mM}$ Gly-Sar was similar to its BL-to-AP permeability. The effect of $10 \mathrm{mM}$ Gly-Sar on AP-to-BL permeability as well as BL-to-AP permeability of Val-FITC-OCH $\mathrm{H}_{3}$ was not determined.

The stability results on the donor Lys-FITC analogue solutions bathing either the apical or basolateral side are shown in Table III. It is seen that the free acid analogue is stable over 90 min with almost no degradation or breakdown of the thiourea linkage when in contact with either side of the Caco-2 monolayers. The methyl ester analogue, however, degraded to the free acid form on the apical side ( $\sim 53 \%$ in 90 min). The degradation of Lys-FITC-OCH${ }_{3}$ was lower when placed on the basolateral side. Further, only the free acid form, Lys-FITC-OH, was detected in the receiver solution in AP-to-BL experiments.

Table II. Transport of FITC Analogues in Caco-2 Cell Monolayers ${ }^{a}$

\begin{tabular}{llc}
\hline & \multicolumn{2}{c}{ Permeability $^{b}\left(\times 10^{6} \mathrm{~cm} / \mathrm{s}\right)$} \\
\cline { 2 - 3 } \multicolumn{1}{c}{ Compound } & AP to BL & BL to AP \\
\hline Lys-FITC-OCH $_{3}$ & $1.47 \pm 0.10$ & $0.20 \pm 0.03$ \\
Lys-FITC-OCH $_{3}+$ GlySar & $0.26 \pm 0.03^{c}$ & nd \\
Val-FITC-OCH & $0.12 \pm 0.02$ & nd \\
Lys-FITC-OH & $1.51 \pm 0.17$ & $0.21 \pm 0.03$ \\
Lys-FITC-OH + GlySar & $0.71 \pm 0.08^{c}$ & nd \\
\hline
\end{tabular}

${ }^{a}$ All values expressed as mean $\pm \mathrm{SD}$ of triplicate determinations at $37^{\circ} \mathrm{C}$.

${ }^{b}$ FITC-Lys analogue concentration, $50 \mu \mathrm{M}$; Gly-Sar concentration, $10 \mathrm{mM}$.

${ }^{c} \mathrm{p} \leq 0.002$ compared to control.
Table III. Stability of FITC Analogues in Caco-2 Cell Monolayers ${ }^{a}$

\begin{tabular}{lcc}
\hline & \multicolumn{2}{c}{ Stability $^{b}$} \\
\cline { 2 - 3 } Compound & AP donor & BL donor \\
\hline Lys-FITC-OCH & $47.6 \pm 5.3$ & $70.4 \pm 1.5$ \\
Val-FITC-OCH & nd & $\sim 100.0$ \\
Lys-FITC-OH & $\sim 100.0$ & \\
\hline${ }^{a}$ All values expressed as mean \pm SD of triplicate determinations at \\
$37^{\circ} \mathrm{C}$. \\
${ }^{b}$ Percentage compound remaining in donor bathing solution at 90 \\
min.
\end{tabular}

\section{DISCUSSION}

There are a wide range of substrates that exhibit affinity for the hPept1 oligopeptide transporter. This substrate flexibility allows the design of prodrugs that are targeted to hPept1 using substrates with an equally wide range of substrate moieties. Thus, it is anticipated that following prodrug design and synthesis, the characterization of hPept1 transporter uptake activity in different cell types in vitro or different tissues in vivo would require the screening of numerous samples. In these situations, suitable alternatives to tedious HPLC or hazardous radioactive assays would be highly beneficial. Fluorescence-based assays not only obviate the use of hazardous materials but also are amenable to rapid screening with multiwell plate readers. The present study demonstrates this applicability with fluorescently labeled analogues using cells with widely differing levels of hPept 1 expression. Thus, HeLa cells, HeLa cells overexpressing hPept1, and normal Caco- 2 cells were analyzed for hPept 1 mRNA expression levels. The semiquantitative RT-PCR results in Fig. 2 indicate that uptake of hPept1 substrates should be consistent with the order of hPept 1 mRNA expression, HeLa $<$ Caco- $2<\mathrm{HeLa} /$ hPept1.

In initial studies, fluorescent analogues of the amino acids valine and lysine were synthesized and tested in HeLa/ hPept 1 cells. The fluorescent moiety fluorescein isothiocyanate (FITC) was linked to the methyl ester of valine via the $\mathrm{N}$-terminal amino group of valine or to the $\mathrm{N}^{\varepsilon}$ amino group of lysine or its methyl ester. The rationale for this synthesis was based on the previously successful amino acid prodrug strategy used with valacyclovir. Modifications were made with the knowledge that the basic structural requirement for peptide transport is the terminal carboxyl group of the amino acid and that the N-terminal of the amino acid could be altered without affecting affinity for the hPept1 transporter (16). The $\left[{ }^{3} \mathrm{H}\right]$ Gly-Sar inhibition results shown in Fig. 3 clearly suggest that both methyl ester FITC analogues have affinity for hPept1. However, the lower affinity of FITC-Val-OCH ( $22 \%$ inhibition), a neutral molecule, may be caused by its enhanced lipophilicity. The 10-fold lower AP-to-BL permeability of FITC-Val-OCH $\mathrm{H}_{3}$ in Caco-2 cells compared to that of Lys-FITC-OCH$H_{3}$ is consistent with its lower peptide transporter affinity. The charged lysine analogue $\mathrm{Lys}-\mathrm{FITC}-\mathrm{OCH}_{3}$, however, exhibited a much higher hPept1 affinity judging from its ability to inhibit $74 \%$ of $\left[{ }^{3} \mathrm{H}\right]$ Gly-Sar uptake in HeLa/ hPept1 cells. The similar AP-to-BL permeabilities of LysFITC-OH and Lys-FITC- $\mathrm{OCH}_{3}$ may suggest that the structural requirements of a peptide bond and a free carboxyl group may not be necessary for hPept 1 recognition and trans- 
port. It is important to note, however, that the permeability of Lys-FITC-OCH${ }_{3}$ was affected to a greater extent in the presence of Gly-Sar, indicating some preference for the methyl ester form by the peptide transporter (Table II).

The high stability of Lys-FITC-OH in Caco-2 monolayer bathing solutions clearly suggests that the thiourea linkage between FITC and lysine remains intact. Thus, the loss of Lys-FITC-OCH${ }_{3}$ from bathing solutions resulted from conversion of the methyl ester to its free acid form. This observation coupled with the finding that AP-to-BL permeability of the two forms in Caco-2 monolayers is similar indicates that such degradation may not be a major factor in uptake determinations. The inability to detect the methyl ester analogue in receiver solutions in AP-to-BL experiments suggests its rapid hydrolysis by brush border membrane enzymes and cytosolic enzymes during transit.

The fluorescence uptake intensities of $100 \mu \mathrm{M}$ LysFITC-OCH ${ }_{3}$ in HeLa, HeLa/hPept1 cells (Fig. 4), and in Caco-2 cells (Fig. 5) determined under similar experimental conditions is consistent with the order of hPept 1 mRNA expression levels in the three systems (Fig. 2). Further, the sig-

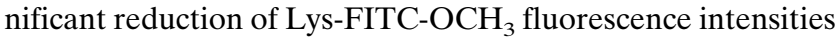
in the presence of Gly-Sar in both HeLa/hPept1 (Fig. 4) and Caco-2 (Fig. 5) cells provides strong evidence for hPept1mediated uptake. The saturable uptake behavior of LysFITC-OCH ${ }_{3}$ with $\mathrm{HeLa} / \mathrm{hPept} 1$ cells at higher Lys-FITC$\mathrm{OCH}_{3}$ concentrations also suggests hPept1 carrier-mediated transport of the analogue. It is possible that Lys-FITC-OCH might also be a substrate for hPept 2 transporter or other peptide transporters. However, the predominance of hPept1 expression in hPept 1 overexpressed HeLa cells and the absence of hPept 2 in Caco- 2 cells indicate that in the two cell systems examined, the contribution of hPept 2 to uptake and transport of Lys-FITC-OCH 3 is quite negligible. Thus, the results suggest that the fluorescent analogue Lys-FITC-OCH exhibits high affinity for hPept1 and that Lys-FITC-OCH uptake in test candidate cells or tissues via the hPept 1 transporter can be conveniently monitored with simple fluorescence measurements.

The Lys-FITC-OCH $\mathrm{OCH}_{3}$ uptake into Caco-2 cells determined using HPLC assays shown in Fig. 6 and uptake into HeLa/hPept1 cells using cell microscopy shown in Fig. 7 provide complementary evidence for uptake of the fluorescent analogue. Further, the inhibitory effects of known hPept1 substrates such as Gly-Sar, Gly-Pro, Gly-Phe, and cephalexin on Lys-FITC-OCH $\mathrm{OH}_{3}$ uptake and transport across Caco-2 cells determined by HPLC analysis as well as the negligible effect of Lys on uptake (Fig. 6 and Table II), clearly suggest that Lys-FITC-OCH $\mathrm{OCH}_{3}$ is transported via the hPept1 transporter. The HPLC results also suggest that monitoring of Lys-FITC$\mathrm{OCH}_{3}$ uptake in cells with fluorescence measurements would be a reliable alternative.

\section{CONCLUSIONS}

In this study, we have demonstrated that the fluorescent analogue Lys-FITC-OCH 3 is a substrate for the hPept 1 transporter. Thus, fluorescent intensities of Lys-FITC-OCH $\mathrm{H}_{3}$ uptake in HeLa, Caco-2, and HeLa/hPept1 cells corresponded to the extent of hPept 1 mRNA expression in the cells. The effect of known hPept1 substrates on Lys-FITC-OCH $\mathrm{OH}_{3}$ uptake in HeLa/hPept1 cells determined using fluorescence measurements was also consistent with hPept1-mediated uptake of the fluorescent analogue. The Lys-FITC-OCH $\mathrm{CH}_{3}$ uptake in Caco- 2 cells and its inhibition by known hPept1 substrates determined with HPLC analyses provided evidence for the reliability of the fluorescence method. The inhibition of Lys-FITC-OCH $\mathrm{OCH}_{3}$ transport in the presence of Gly-Sar in Caco- 2 cells and the direct evidence of chromophore localization in the cytoplasm and nucleus corroborate the fluorescence uptake studies. Finally, although the fluorescence uptake methodology described in this study is not set up as a high-throughput strategy, it can be easily adapted for such an approach. It is anticipated that with such a high-throughput method, large numbers of cell samples can be screened rapidly and accurately for hPept1 uptake activity.

\section{ACKNOWLEDGMENTS}

We thank Dr. Balvinder S. Vig for expert help with ESIMS and valuable discussions during the preparation of this manuscript. This work was supported by NIH grant GM 37188.

\section{REFERENCES}

1. W. Kramer, C. Dechent, F. Girbig, U. Gutjahr, and H. Neubauer Intestinal uptake of dipeptides and beta-lactam antibiotics. I. The intestinal uptake system for dipeptides and beta-lactam antibiotics is not part of a brush border membrane peptidase. Biochim. Biophys. Acta 1030:41-49 (1990).

2. K. Inui, Y. Tomita, T. Katsura, T. Okano, M. Takano, and R. Hori. $\mathrm{H}^{+}$coupled active transport of bestatin via the dipeptide transport system in rabbit intestinal brush-border membranes. $J$. Pharmacol. Exp. Ther. 260:482-486 (1992).

3. M. Hu and G. L. Amidon. Passive and carrier-mediated intestinal absorption components of captopril. J. Pharm. Sci. 77:1007-1011 (1988).

4. M. A. Jacobson, P. de Miranda, D. M. Cederberg, T. Burnette, E. Cobb, H. R. Brodie, and J. Mills. Human pharmacokinetics and tolerance of oral ganciclovir. Antimicrob. Agents Chemother. 31: 1251-1254 (1987).

5. P. de Miranda and M. R. Blum. Pharmacokinetics of acyclovir after intravenous and oral administration. J. Antimicrob. Chemother. 12(Suppl B):29-37 (1983).

6. S. Weller, M. R. Blum, M. Doucette, T. Burnette, D. M. Cederberg, P. de Miranda, and M. L. Smiley. Pharmacokinetics of the acyclovir pro-drug valaciclovir after escalating single- and multiple-dose administration to normal volunteers. Clin. Pharmacol. Ther. 54:595-605 (1993).

7. D. Jung and A. Dorr. Single-dose pharmacokinetics of valganciclovir in HIV- and CMV-seropositive subjects. J. Clin. Pharmacol. 39:800-804 (1999).

8. H. K. Han, D. M. Oh, and G. L. Amidon. Cellular uptake mechanism of amino acid ester prodrugs in Caco-2/hPEPT1 cells overexpressing a human peptide transporter. Pharm. Res. 15:13821386 (1998).

9. M. Sugawara, W. Huang, Y. J. Fei, F. H. Leibach, V. Ganapathy, and M. E. Ganapathy. Transport of valganciclovir, a ganciclovir prodrug, via peptide transporters PEPT1 and PEPT2. J. Pharm. Sci. 89:781-789 (2000).

10. D. E. Gonzalez, K. M. Covitz, W. Sadee, and R. J. Mrsny. An oligopeptide transporter is expressed at high levels in the pancreatic carcinoma cell lines AsPc-1 and Capan-2. Cancer Res. 58:519-525 (1998)

11. C. J. Whitaker, S. H. Battah, M. J. Forsyth, C. Edwards, R. W. Boyle, and E. K. Matthews. Photosensitization of pancreatic tumour cells by delta-aminolaevulinic acid esters. Anticancer Drug Des. 15:161-170 (2000).

12. D. A. Groneberg, F. Doring, P. R. Eynott, A. Fischer, and H. Daniel. Intestinal peptide transport: ex vivo uptake studies and localization of peptide carrier PEPT1. Am. J. Physiol. Gastrointest. Liver Physiol. 281:G697-G704 (2001). 
13. H. Abe, M. Satoh, S. Miyauchi, S. Shuto, A. Matsuda, and N. Kamo. Conjugation of dipeptide to fluorescent dyes enhances its affinity for a dipeptide transporter (PEPT1) in human intestinal Caco-2 cells. Bioconjug. Chem. 10:24-31 (1999).

14. C. P. Hsu, J. M. Hilfinger, E. Walter, H. P. Merkle, B. J. Roessler, and G. L. Amidon. Overexpression of human intestinal oligopeptide transporter in mammalian cells via adenoviral transduction. Pharm. Res. 15:1376-1381 (1998).
15. H.-K. Han, R. L. A. de Vrueh, J. K. Rhie, K.-M. Y. Covitz, P. L. Smith, C.-P. Lee, D.-M. Oh, W. Sadee, and G. L. Amidon. 5'Amino acid esters of antiviral nucleosides, acyclovir, and AZT are absorbed by the intestinal PEPT1 peptide. Pharm. Res. 15: 1154-1189 (1998).

16. E. Walter, T. Kissel, and G. L. Amidon. The intestinal peptide carrier: A potential transport system for small peptide derived drugs. Adv. Drug Deliv. Rev. 20:33-58 (1996). 